\title{
A Comparison of Functional Movement Abilities of Elite Male Soccer and Handball Players
}

\section{Elit Erkek Futbol ve Hentbol Oyuncularınin Fonksiyonel Hareket Becerilerinin Karşılaştırılması}

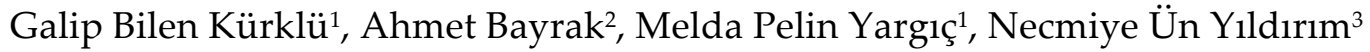 \\ ${ }^{1}$ Sports Medicine Department, Meram Faculty of Medicine, Necmettin Erbakan University, Konya, Turkey \\ ${ }^{2}$ Vocational School of Health Sciences, Selçuk University, Konya, Turkey \\ ${ }^{3}$ Department of Physiotherapy and Rehabilitation, Faculty of Health Sciences, Yıldırım Beyazıt University, Ankara, Turkey
}

G. Bilen Kürklü 0000-0002-0200-529X

A. Bayrak

0000-0002-4431-0524

M. P. Yargıç

0000-0003-4487-5602

N. Ün Yıldırım

0000-0002-5527-4290

Geliş Tarihi/Date Received: 12.11.2018

Kabul Tarihi/Date Accepted: 14.12.2018

Yayın Tarihi/Published Online: 19.12.2018

\section{Yazışma Adresi /}

Corresponding Author:

Galip Bilen Kürklü

Necmettin Erbakan Üniversitesi

Meram Tıp Fakültesi, Spor

Hekimliği Anabilim Dalı

Konya, Türkiye

E-mail: bilenkurklu@gmail.com

(C)2018 Türkiye Spor Hekimleri Derneği. Tüm hakları saklıdır.

\section{ABSTRACT}

Introduction: Both handball and soccer athletes are under high risk of injury, therefore evaluations that assist injury prevention are of high importance. Functional Movement Screening (FMS ${ }^{\mathrm{TM}}$ ) is a test tool used for evaluating athletes' movement capacity and injury risk. The purpose of this study is to measure and compare the functional movement capacities and asymmetries in professional soccer and handball players.

Methods: This study compared FMS ${ }^{\mathrm{TM}}$ scores of 22 elite male soccer players to 24 elite male handball players. FMS $^{\mathrm{TM}}$ consists of an evaluation of seven basic movements, scored from 0 to 3 .

Results: Mean total FMS ${ }^{\mathrm{TM}}$ scores were $15.65 \pm 1.69$ and $16.75 \pm 1.87$ for handball and soccer players, respectively. After analyzing the sub-parameters, handball players displayed more asymmetry in shoulder mobility test as well as in in-line lunge $(p<0.05)$.

Conclusions: With lower overall FMS $^{\mathrm{TM}}$ scores and higher asymmetry scores, handball players may be under higher risk of injury compared to soccer players.

Keywords: Sports injuries, soccer, handball.

\section{ÖZ}

Amaç: Futbol ve hentbol spor yaralanmalarının sık görüldüğü branşlardır, bu nedenle yaralanmadan koruyucu olabilecek değerlendirmeler önem arz etmektedir. Fonksiyonel Hareket Taraması (FMS ${ }^{\mathrm{TM}}$ ) sporcuların hareket becerilerini ve yaralanma risklerini değerlendiren bir test bataryasıdır. Bu araştırmanın amacı profesyonel hentbol ve futbolcuların fonksiyonel hareket kapasiteleri ile asimetrilerinin karşılaştırılmasıdır.

Gereç ve Yöntemler: Bu çalışmada 22 elit erkek futbolcu ile 24 elit erkek hentbolcunun $\mathrm{FMS}^{\mathrm{TM}}$ skorları karşılaştırılmıştır. $\mathrm{FMS}^{\mathrm{TM}}$ analizi yedi temel hareketin değerlendirilip her harekete 0-3 arası bir skor verilmesi ile yapılmaktadır.

Bulgular: Ortalama total FMS $^{\text {TM }}$ skorları, hentbol ve futbolcular için sırasıyla $15.65 \pm 1.69$ ve $16.75 \pm 1.87$ olarak bulundu. Alt parametreler araştırıldığında, omuz mobilite testi ve in-line lunge hareketlerinde hentbol oyuncuları daha asimetrik bulundu. $(p<0.05)$.

Sonuç: Daha düşük total $\mathrm{FMS}^{\mathrm{TM}}$ skorları ve yüksek asimetri skorları göz önüne alındığında hentbol sporcularının futbolculara kıyasla yaralanma risklerinin daha yüksek olduğu söylenebilir.

Anahtar Sözcükler: Spor yaralanmaları, futbol, hentbol 
Available at: http://journalofsportsmedicine.org and http://dx.doi.org/10.5152/tjsm.2019.129

Cite this article as: Kurklu GB, Bayrak A, Yargic MP et al. A comparison of functional movement abilities of elite male soccer and handball players. Turk J Sports Med. 2019;54(3):169-74.

\section{INTRODUCTION}

Both handball and soccer athletes are under high risk of injury, therefore evaluations that assist injury prevention are of high importance. Professional soccer players possess 1000 times more injury risk than common industrial professions. Professional soccer players' injury rates were reported as 8.5 injuries per 1000 hours between 1994-1997 and as 9.4 per 1000 hours during the 2001-2002 season $(1,2)$. An 11-year follow up study of UEFA Champions League reported 7.6 injuries per 1000 hours (95\% Confidence Interval 7.4 to 7.8 ), and revealed that match injury rates were almost seven times higher than training injury rates (26.7 vs $4.0 / 1000 \mathrm{~h}, \mathrm{RR} 6.7,95 \%$ CI 6.4 to 7.0 , $\mathrm{p}<0.001$ ) (3). On the other hand, injury prevalence for young handball players during one season was $53.60 \%$ (4). The injury incidence rates among elite Brazilian handball players were reported as $3.7 / 1000 \mathrm{~h}$ during training and 20.3/1000 h during matches (5). Most affected body regions by traumatic injuries in handball players are ankle and knee. Shoulder and knee are most commonly affected by overuse injuries. Muscle injuries, sprains and contusions are the most common traumatic injury types, whereas the most common overuse injury is tendinopathy (5). On the other hand, lower extremities are the most commonly injured regions in soccer, namely the thigh, knee, ankle and hip/groin. Muscle strain, ligament sprain and contusion are the most common injury types (6).

Numerous clinical movement screening tests have been developed over the years in order to predict and prevent sports injuries. Some of the widely used screening tests are as follows: Functional Movement Screen ${ }^{\mathrm{TM}}\left(\mathrm{FMS}^{\mathrm{TM}}\right)$, Star Excursion Balance Test, Y Balance Test, Drop Jump Screening Test, Landing Error Scoring System, and the Tuck Jump Analysis (7). FMS ${ }^{\mathrm{TM}}$, designed by Cook and colleagues (8), is a reliable instrument with consistent scoring criteria (7). FMS ${ }^{\mathrm{TM}}$ consists of seven basic movement tests that require both mobility and stability. The result is used in order to estimate injury risk. Minick and colleagues have shown that $\mathrm{FMS}^{\mathrm{TM}}$ has high interrater reliability (9). Injury risk of athletes with a total $\mathrm{FMS}^{\mathrm{TM}}$ score of 14 or less is found to be higher (10). Among American football players, FMS $^{\mathrm{TM}}$ scores less than 14 were significantly associated with serious injuries (11). Low $\mathrm{FMS}^{\mathrm{TM}}$ scores are able to predict injuries in firefighters as well (12). Although evidence on injury predicting capabilities of $\mathrm{FMS}^{\mathrm{TM}}$ is still limited, it is a widely used tool among sports professionals, probably due to its low cost and simplicity to implement. Use of $\mathrm{FMS}^{\mathrm{TM}}$ is not limited to athletic world either, it is also applied for chronic conditions in non-athletic populations, such as chronic back problems and chronic ankle instability $(13,14)$.

Functional movement is defined as the balance established between mobility and stability while performing basic movements in a correct and efficient manner. Functional movements can be affected by lack of proprioception or postural control. FMS ${ }^{\mathrm{TM}}$ also assesses quality and possible limitations of basic locomotive movements and asymmetries in exhibited movements. Asymmetry and compensatory movements may be associated with injury risk, therefore identification of these are also crucial.

\section{MATERIAL AND METHODS}

Ethics approval was obtained for this study from Necmettin Erbakan University Ethics Committee (2017/948). Informed consent was obtained from all individual participants included in the study. This research involved 22 male soccer players and 24 male handball players. Handball team competed in the Turkish Male Handball Super League and soccer team competed in the U19 Elite League A at the time of the research. 
Both teams were based in the same city and both teams had a training schedule of 4 sessions a week, each session averaging 1.5 hours. Functional movement screen was conducted by a physical therapist from the research team. Seven movements were assessed: hurdle step, in-line lunge, shoulder mobility, trunk push-up, deep squat, active straight leg raise, rotator stability. Movements were scored using a standard 0-3 ordinal system. Scoring was done as follows: 0 if pain was present, 1 if the athlete failed to complete the movement, 2 if the movement was completed with compensatory movements and 3 if movement was performed perfectly.

All athletes were tested in the afternoon before training. Both of teams were tested in preseason training period. During evaluation, two high-resolution cameras were used and recordings were utilized for analysis. For determining asymmetry, the difference between right and left measurements was calculated for each test. The difference greater than 1 considered as asymmetry. In order to compare the average and total FMS $^{\text {TM }}$ scores among groups, independent T-test was used. $\chi 2$ - test was applied for categorical variables, Fisher's Exact was used for $2 \times 2$ charts and odds ratio was assessed. Statistical analysis was performed using SPSS v20.0.

\section{RESULTS}

Demographic and anthropometric characteristics of handball and soccer players are listed in Table 1. Handball players were significantly taller and had higher body weight compared to soccer players. However, there were no significant differences between groups regarding age and body mass indexes (BMI).

Table 1. Anthropometric and demographic characteristics of the players ( $n=24$ for handball, $n=22$ for soccer)

\begin{tabular}{llll}
\hline & & Mean \pm SD & p values \\
\hline \multirow{2}{*}{ Height } & Handball & $182.21 \pm 7.12$ & $\mathrm{p}<0.05$ \\
& Soccer & $177.18 \pm 6.6$ & \\
\multirow{2}{*}{ Weight } & Handball & $80.58 \pm 18.38$ & $\mathrm{p}<0.05$ \\
& Soccer & $71.27 \pm 8.62$ & \\
Age & Handball & $20.50 \pm 5.26$ & $\mathrm{p}>0.05$ \\
& Soccer & $18.91 \pm 1.07$ & \\
BMI & Handball & $24.11 \pm 4.29$ & $\mathrm{p}>0.05$ \\
& Soccer & $22.67 \pm 2.16$ & \\
\hline
\end{tabular}

BMI: Body mass index, SD: standard deviation

FMS $^{\mathrm{TM}}$ average and total scores for handball and soccer groups are presented in Table 2. A significant difference between two groups in terms of total scores and average scores was observed $(\mathrm{p}<0.05)$. Total and average scores of handball players were lower than soccer players.
In the FMS $^{\mathrm{TM}}$ analysis, cut-off value for injury prediction is accepted as $\leq 14.4(10)$. 4 handball players and 1 soccer player scored below 14.4. Total asymmetry is accepted to be evident if athlete had at least one asymmetry in four movements (Table 3.) 
Table 2. FMS $^{\mathrm{TM}}$ average and total scores

\begin{tabular}{cccc}
\hline & Handball & Soccer & p \\
\hline FMSTMMovement Total $^{\text {TMM }}$ & $15.65 \pm 1.69$ & $16.75 \pm 1.87$ & $\mathrm{p}<0.05$ \\
FMS $^{\text {TM }}$ Group Average & $2.23 \pm 0.25$ & $2.40 \pm 0.28$ & $\mathrm{p}<0.05$ \\
\hline
\end{tabular}

Values are presented as mean \pm standard deviation.

Table 3. Asymmetry status of soccer and handball athletes in four movements

\begin{tabular}{|c|c|c|c|c|c|}
\hline & \multicolumn{2}{|c|}{ Soccer } & \multicolumn{2}{|c|}{ Handball } & \multirow{2}{*}{$\begin{array}{c}\text { Comparison } \\
\text { between soccer and } \\
\text { handball teams for } \\
\text { each movement }\end{array}$} \\
\hline & Asymmetry & No asymmetry & Asymmetry & No asymmetry & \\
\hline Hurdle step & 1 & 22 & 5 & 19 & $\chi 2=2.68 p>0.05$ \\
\hline In-line lunge & 1 & 22 & 7 & 17 & $\chi 2=4.84 p<0.05$ \\
\hline Leg raise & 2 & 20 & 2 & 22 & $\chi 2=0.00 \quad p>0.05$ \\
\hline $\begin{array}{l}\text { Shoulder } \\
\text { mobility }\end{array}$ & 1 & 21 & 9 & 15 & $\chi 2=7.32 p<0.05$ \\
\hline $\begin{array}{c}\text { Total } \\
\text { asymmetry }\end{array}$ & 5 & 17 & 16 & 8 & $\chi 2=8.93 p<0.05$ \\
\hline
\end{tabular}

\section{DISCUSSION}

This research compared the FMS $^{\text {TM }}$ scores of 24 elite male handball players to 22 elite male soccer players. Instead of comparing handball and soccer teams that both compete in their Super League, it was preferred to analyze a handball team from Turkish Male Handball Super League and a soccer team from U19 Elite League $A$, because the training intensity and frequency of a Super League soccer team was much higher than a Super League handball team, also the number of matches they played and the number of tournaments they attended in one season were different. These two teams were more similar by means of training and match intensity and frequency. In this study, it was found that elite soccer players had higher FMS $^{\mathrm{TM}}$ scores than handball players. There is limited amount of research that compares functional movement scores of athletes from different sports branches. In 2016, Tafuri et al. compared $\mathrm{FMS}^{\mathrm{TM}}$ scores of body-builders, professional weight-lifters and CrossFit athletes.
Mean score of CrossFit group was found to be higher than the others (CrossFitters 15.2 \pm 1.7 , weight-lifters $14.8 \pm 2$ and body-builders $14.2 \pm 1.9$ ). On the other hand, CrossFitters were more symmetric than others (15). In the current study, soccer team players were more symmetric than handball players.

When total $\mathrm{FMS}^{\mathrm{TM}}$ scores of $1^{\text {st }}$ and $2^{\text {nd }}$ Division Polish handball players were compared, mean scores of players from the 1st Division were reported as $15.5 \pm 1.9$, and of players from the 2nd Division as $15.4 \pm 2.6$ points (16). This study aimed to evaluate potential risk of injury among handball players. 30 handball players were evaluated using the functional movement screen and athletes were reevaluated after 6 months. Authors have concluded that $\mathrm{FMS}^{\mathrm{TM}}$ may be a useful tool to identify certain adaptations in shoulders of handball players (16).

In 2007, Kiesel et al. conducted a research including 46 soccer players and reported that average score of injured players was 14.3 while it was 17.4 for the healthy ones (11). As a result, 
it was stated that FMS ${ }^{\mathrm{TM}}$ could be used in injury risk prediction. In our study, 1 soccer player out of 22 scored below 14 points, while other 21 players scored above. Injury history of the player that scored below 14 was congruent with the test result.

An interesting research demonstrated that origin of the player also affected the fundamental movement competency in professional baseball players. Dominican Republic born players had better right sided shoulder mobility, whereas United States born players had better active leg raise and trunk stability push-up scores (17). Our participants were not diverse enough in means of origin, therefore we were unable to test the effect of origin in our study.

Researchers have reported that body mass index and body composition are important factors in functional movement scoring in college football athletes. Obese athletes have scored less in total; as well as in deep squat, hurdle step and in-line lunge. There was also a significant negative correlation between composite $\mathrm{FMS}^{\mathrm{TM}}$ and body fat percentage (18). Another study that investigated correlation between body composition and functional movement scores in elite volleyball, soccer and rugby players reported similar results. They have also come to the conclusion that there is negative correlation between percentage of fat mass, upper arm fat area and FMS $^{\mathrm{TM}}$ total score (19). Obese athletes may be common in college football players but not among elite soccer and handball players. There were no obese athletes in our study, therefore we could not talk about the effect of body mass index on FMS $^{\mathrm{TM}}$; and we did not have body composition measurements of the participants. For that reason, we are unable to comment on the correlation of body composition and functional movement scores in our study. The latter study also compared the scores of volleyball, soccer and rugby players in means of FMS ${ }^{\mathrm{TM}}$. They have found that rugby players have the lowest total scores, whereas the volleyball players had the highest.
To our knowledge, there is no research published that compare the $\mathrm{FMS}^{\mathrm{TM}}$ scores of elite male soccer and handball players. However, Letfatkar et al. evaluated the FMS ${ }^{\text {TM }}$ scores of male and female soccer, basketball and handball players. Unfortunately, within this research there was not any comparison between sports branches and average scores of all athletes, but the average score of all male athletes was reported as 16.9 (20). Average score of soccer and handball players in our study was 16.17 , which was similar to the abovementioned results of Letfatkar et al. In the current study, it was aimed to compare FMS ${ }^{\text {TM }}$ scores of an upper extremity dominant team sport players with a lower extremity dominant team sport players. Future research may include a full season injury profile of such two teams and investigate the correlation of the injury severity, location and type with preseason FMS $^{\text {TM }}$ scores.

In 2017, Lubiatowski et al. analyzed glenohumeral adaptation and shoulder pathologies in professional male handball players and found a correlation between shoulder rotation deficits and shoulder pain and impingement syndrome (21). It was stated that shoulder rotation evaluation proved injury risk in handball players. In a research by Edouard et al. in 2013, it was found out that internal and external rotation muscle imbalance resulted in high injury risk (22). In our study handball players showed higher shoulder asymmetry than soccer players which implied that handball players might be under higher risk of shoulder injury.

There are several limitations of this study. First of all, the sample size is limited to one team members from two sports branches. This impairs the generalizability of the study. Another limitation is the lack of follow-up of the teams. Reporting the actual injury rates of these two teams for at least one full season would increase the strength of the study.

\section{CONCLUSION}

It was found that soccer players had higher total FMS $^{\text {TM }}$ scores than handball players, which showed that soccer players displayed better 
functional movement patterns. Soccer players' movements were also more symmetric than handball players. Handball players had higher shoulder internal and external rotation asymmetry. According to FMS $^{\mathrm{TM}}$ scores, it was assumed that the players of the handball team had higher risk of injury compared to soccer team.

Acknowledgments: We would like to thank all the athletes who participated in this research and their team staff.

\section{REFERENCES}

1. Hawkins RD, Fuller CW. A prospective epidemiological study of injuries in four English professional football clubs. Br J Sports Med 1999 Jun;33(3):196-203.

2. Waldén $M$, Hägglund M, Ekstrand J. UEFA Champions League study: a prospective study of injuries in professional football during the 2001-2002 season. $\mathrm{Br}$ J Sports Med . 2005 Aug ;39(8):542-6.

3. Ekstrand J, Hägglund $M$, Kristenson $K$, Magnusson $H$, Waldén M. Fewer ligament injuries but no preventive effect on muscle injuries and severe injuries: an 11year follow-up of the UEFA Champions League injury study. Br J Sports Med . 2013 Aug ;47(12):732-7.

4. Higashi RH, Santos MB, Castro GTM de, Ejnisman B, Sano SS, Cunha RA Da. Lesões musculoesqueléticas em jovens atletas de handebol: um estudo transversal. Fisioter e Pesqui . 2015 ;22(1):84-9.

5. Giroto N, Hespanhol Junior LC, Gomes MRC, Lopes AD. Incidence and risk factors of injuries in Brazilian elite handball players: A prospective cohort study. Scand J Med Sci Sports . 2017 Feb ;27(2):195-202.

6. Ekstrand J, Hägglund M, Waldén M. Injury incidence and injury patterns in professional football: the UEFA injury study. Br J Sports Med . 2011 Jun 1 ;45(7):553-8.

7. Chimera NJ, Warren M. Use of clinical movement screening tests to predict injury in sport. World $J$ Orthop . 2016 Apr 18 ; (4):202-17.

8. Cook G, Burton L, Hoogenboom BJ, Voight M. Functional movement screening: the use of fundamental movements as an assessment of function - part 1. Int J Sports Phys Ther . 2014 May ;9(3):396409.

9. Minick KI, Kiesel KB, Burton L, Taylor A, Plisky P, Butler RJ. Interrater Reliability of the Functional Movement Screen. J Strength Cond Res . 2010 Feb ;24(2):479-86.

10. Chorba RS, Chorba DJ, Bouillon LE, Overmyer CA, Landis JA. Use of a functional movement screening tool to determine injury risk in female collegiate athletes. $N$ Am J Sports Phys Ther . 2010 Jun ;5(2):47-54.
11. Kiesel K, Plisky PJ, Voight ML. Can Serious Injury in Professional Football be Predicted by a Preseason Functional Movement Screen? N Am J Sports Phys Ther . 2007 Aug ;2(3):147-58.

12. Butler RJ, Contreras M, Burton LC, Plisky PJ, Goode A, Kiesel K. Modifiable risk factors predict injuries in firefighters during training academies. Work. 2013 Jan $1 ; 46(1): 11-7$.

13. Ko M-J, Noh K-H, Kang M-H, Oh J-S. Differences in performance on the functional movement screen between chronic low back pain patients and healthy control subjects. J Phys Ther Sci . 2016 Jul ;28(7):20946.

14. Choi H-S, Shin W-S. Validity of the lower extremity functional movement screen in patients with chronic ankle instability. J Phys Ther Sci . 2015 Jun ;27(6):1923-7.

15. Tafuri S, Notarnicola A, Monno A, Ferretti F, Moretti B. Crossfit athletes exhibit high symmetry of fundamental movement patterns. A cross-sectional study. Muscles Ligaments Tendons J . 2016 ;6(1):15760.

16. Slodownik R, Ogonowska-Slodownik A, MorgulecAdamowicz N. Functional Movement ScreenTM and history of injury in the assessment of potential risk of injury among team handball players. J Sports Med Phys Fitness . 2018 Sep [cited 2018 Oct 8];58(9):1281-6.

17. Bullock GS, Chapman T, Joyce T, Prengle R, Stern T, Butler RJ. Examining Differences in Movement Competency in Professional Baseball Players Born in the United States and Dominican Republic. J Sport Rehabil . 2018 Sep 5 [cited 2018 Oct 8];27(5):397-402.

18. Nicolozakes CP, Schneider DK, Roewer BD, Borchers JR, Hewett TE. Influence of Body Composition on Functional Movement ScreenTM Scores in College Football Players. J Sport Rehabil . 2018 Sep 19 [cited 2018 Oct 8];27(5):431-7.

19. Campa F, Piras A, Raffi M, Toselli S. Functional Movement Patterns and Body Composition of HighLevel Volleyball, Soccer and Rugby Players. J Sport Rehabil . 2018 Sep 17 [cited 2018 Oct 8];1-20.

20. Letafatkar A, Hadadnezhad M, Shojaedin S, Mohamadi E. Relationship between functional movement screening score and history of injury. Int J Sports Phys Ther . $2014 \mathrm{Feb} ; 9(1): 21-7$.

21. Lubiatowski P, Kaczmarek P, Cisowski P, Breborowicz E, Grygorowicz M, Dzianach $M$, et al. Rotational glenohumeral adaptations are associated with shoulder pathology in professional male handball players. Knee Surgery, Sport Traumatol Arthrosc . 2018 Jan 15 ;26(1):67-75.

22. Edouard P, Degache F, Oullion R, Plessis J-Y, GleizesCervera S, Calmels P. Shoulder Strength Imbalances as Injury Risk in Handball. Int J Sports Med . 2013 Feb 26 ;34(07):654-60. 